Hitler, moreover, was known to have a morbid fear of cancer and may himself have sanctioned Warburg's reclassification from half-Jewish to quarter-Jewish to circumvent the race laws. At all events, he spent a tranquil war, pursuing his researches, and was permitted even to maintain his stable of thoroughbreds.

In 1945 the Russians arrived and Warburg levanted to his country house on the island of Rügen, leaving the surviving members of his staff to protect the institute as best they could against the rapine of the occupiers. This act of abnegation caused much rancour. One of the most absorbing passages of the book is a long extract from the diary of Warburg's assistant, Lüttgens, chronicling the life of the institute during this tumultuous period. In the end the contents of the laboratory were packed into crates and shipped off to Russia. Left without the means to carry on experimental science, Warburg dedicated himself to writing two monographs, full of invective against his scientific rivals. There followed a disastrous visit to the United States at the invitation of Robert Emerson, who hoped that the issue of the quantum yield of photosynthesis, which had become a running sore, could be cleared up by collaborative experimental work in Chicago. Warburg could not bring himself to concede defeat and left in a huff. The death of his old adversary James Franck did not appease his wrath; he took exception to a generous obituary and wrote an intemperate rejoinder in a journal. In a letter to Krebs, Max Delbrück expresses his disgust at the manner in which Warburg conducted his polemics and owned that this alone had deterred him from entering the field.

In 1953, Warburg at last took possession of a fine new research institute that the Max-Planck Society had built for him in Dahlem. He was then 70 and was to continue working for another 17 years and 240 papers, up to two days before his death, which was greeted with thunderous eulogies.

Petra Werner has skilfully resurrected the scaly old basilisk for her readers and illuminated a richly interesting period of scientific history. Her book admirably complements Krebs's biographical memoir of 11 years ago (Otto Warburg: Cell Physiologist, Biochemist and Eccentric). There is a well-chosen collection of photographs. The title - an assertion that is not perhaps borne out by the circumstances of Warburg's life (or by that of many other geniuses) - comes from a tribute by M. L. Anson, Warburg's one loyal American admirer.

Walter Gratzer is in the MRC Muscle and Cell Motility Unit, King's College, Drury Lane, London WC2B 5RL, UK.

NATURE · VOL $356 \cdot 16$ APRIL 1992

\section{The politics of our genes}

\section{W. F. Bynum}

Eugenics, Human Genetics and Human Failings: The Eugenics Society, its Sources and its Critics in Britain. By Pauline M. H. Mazumdar. Routledge: 1992. Pp. 373. £40, $\$ 74.50$.

IT is an historical commonplace that the eugenics movements of half a century ago were fuelled by race in Germany and the United States, and by class in Britain. American eugenicists were concerned with immigration, especially from Asia and Eastern Europe; German eugenicists with the presence of Jews and other 'non-aryans' in their midst; and the British with their perceived class-related differences in fertility. After the atrocities of the Nazis were exposed, eugenics acquired a dirty name, and post-war science and social policy played down hereditary determinants in favour of social, cultural and environmental ones. And eugenics remains as a salutary tale of ideology and intolerance masquerading as science; repression pretending to be progress.

Like many commonplaces, this one contains the virtue of first-order explanatory power, but little more. As Pauline Mazumdar's study of Britain's Eugenics Society makes clear, there was never a complete consensus among the society's members, either in terms of the 'facts' of human inheritance or the consequences for human betterment to be drawn from them. Nor, in her account, was the revulsion caused by the holocaust a major reason why the Eugenics Society was not the force in the 1950 s that it had been a couple of decades earlier. Rather, she attributes this decline largely to the changed social climate of the early years of the Welfare State, and to the sustained criticism of eugenic methods and assumptions by a number of British scientists, mostly of left-wing politics, and including Lancelot Hogben, J. B. S. Haldane (the centenary of whose birth falls this year) and Lionel Penrose. In particular, the favourite method of the eugenicists - the collecting and evaluation of elaborate human pedigrees was discredited and replaced by the more sophisticated tools of factor analysis and chromosome linkage. These, Hogben insisted, were ethically neutral and could yield a sound science of human heredity. Ironically, they derived much inspiration from German mathematical models - Vererbungsmathematick - and their application to the analysis of human blood groups.

Mazumdar offers a shrewd and largely convincing interpretation of the interplay of politics and science in the work of Hogben, Haldane and Penrose, even if she never actually confronts the issue of why human genetics after the Second World War might be thought to be more value-free than the eugenics it replaced. Insofar as there was an experimentum crucis, it was probably Penrose's survey of 1,280 cases of mental subnormality, carried out in the 1930s at the Royal Eastern Counties Institution at Colchester. His brief was to examine patients who had been diagnosed as mentally defective and to determine the relative roles of heredity and other factors in the aetiology of their condition. Apart from those with the specific conditions of Down's syndrome and phenylketonuria, he found it impossible to categorize most of the patients with precision, and they had rather boring and unrevealing family histories.

Studies such as Penrose's did much to undermine eugenic claims that pedigree studies unambiguously demonstrated the hereditary nature of many undesirable social traits, and the preponderance of these traits in the social class that was often called the residuum. Nevertheless, Mazumdar correctly emphasizes that any crude polarization of students of human heredity in the 1930s into eugenic and anti-eugenic camps is misleading. The longtime secretary of the Eugenic Society, Carlos P. Blacker (inexplicably rechristened 'Charles' by Mazumdar) managed to remain on good terms with many who were critical of the society's aims and methods, publishing one of Hogben's papers in a volume he edited, and trying to adapt the society's policies to the political realities of Britain after the Second World War. More generally, eugenicists and their critics often came from similar backgrounds, sat on many of the same committees, saw each other socially and read each other's books and papers. The centre of gravity of much of Mazumdar's book is the senior common room at University College London, where Karl Pearson, Cyril Burt (dubbed 'Cecil' in the index of this book), Haldane and Penrose taught.

This institutional context of eugenics and its critics was presented rather more explicitly in Daniel J. Kevles' In the Name of Eugenics (Knopf, New York 1985; Penguin, London, 1986), and readers of that splendid monograph will find much in Mazumdar's study that is already familiar. They will also recognize that Mazumdar's rather stolid style is a far cry from the lightness of Kevles' erudition. Nevertheless, Mazumdar has not simply been treading in Kevles' footsteps. She offers some new insights into the background of the Eugenics Society, the influence of German mathematics on British geneticists and the changing offi- 
cial preoccupations of the Eugenics Society, particularly in relation to the nature of and possible remedies for mental disorder and mental subnormality. One would hardly trade this volume for that of Kevles; but neither should we discount the value of Mazumdar's own contributions to a theme still pregnant for us, the generation of the genome.

W. F. Bynum is at the Wellcome Institute for the History of Medicine, 183 Euston Road, London NW1 2BN, UK.

- In The Hour of Eugenics: Race, Gender, and Nation in Latin America, Nancy Leys Stepan compares the eugenics movements in Mexico, Brazil and Argentina with those of Britain, the United States and Germany. Published by Cornell University Press, price $\$ 31.50$.

\section{Mere platonic invention?}

\author{
Colin Renfrew
}

The Flood from Heaven: Deciphering the Atlantis Legend. By Eberhard Zangger. Sidgwick and Jackson: 1992. Pp. 256. 17.50, \$22. (To be published in the United States by William Morrow on 20 August.)

Plato has a lot to answer for. In setting out the story of the vanished civilization of Atlantis (for which his writings are the only source), he has been the root cause of a great deal of unprofitable speculation. Some of the speculation has been fanciful beyond the bounds of reason, whereas other versions, such as that presented in this book, are honest attempts to make some sense of what he wrote. The story as reported by Plato (allegedly told by priests in Egypt to the Greek sage Solon some centuries earlier) places the doomed civilization in the Atlantic Ocean, and its demise some 9,000 years before Plato. In the light of current understanding, neither of these claims can be correct, and all modern authorities who take the story seriously are obliged to alter both the location and the date. That is where the trouble begins.

In recent years, a favourite contender has been the volcanic island of Thera in the Cyclades. For here, at least, was a worthy cataclysm, resulting in the destruction and burial of the Bronze Age city somewhere around the seventeenth century BC at what is now Akrotiri. Several authors have claimed that Thera fits the bill - as it may well do if place, time and other details are conveniently varied. For a while, the entire civilization of Minoan Crete was seen as a candidate, the collapse of the Minoan

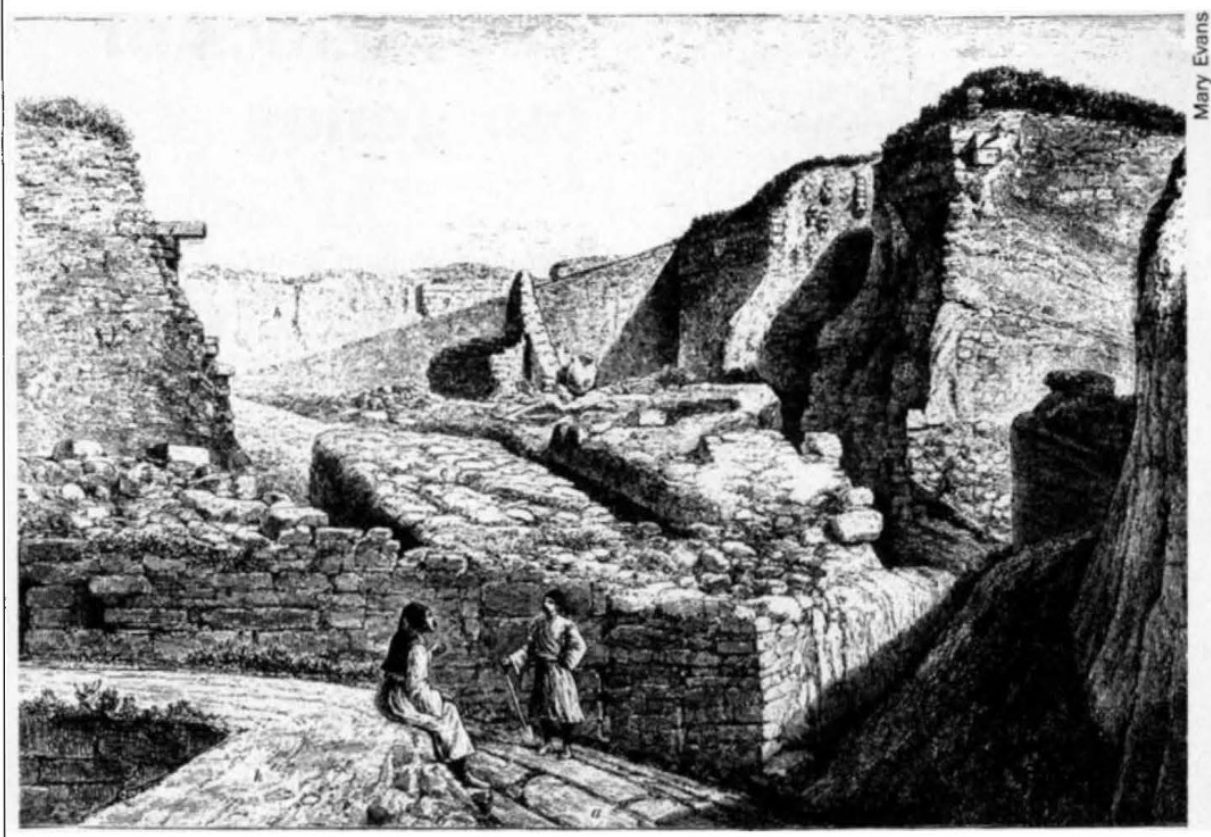

Digging for Atlantis? Excavation of Hissarlik, claimed as Troy, by $\mathrm{H}$. Schliemann in 1873.

palaces being plausibly attributed to the Thera eruption. But that suggestion no longer finds favour, and another Atlantis theory vanishes beneath the waters.

Eberhard Zangger has an alternative and ingenious candidate: for him Atlantis equals Troy. As a geomorphologist, he is well placed to argue that the ancient topography of the site of Hissarlik, excavated and claimed as Troy by Heinrich Schliemann, has changed significantly since the time of the Trojan War, some 3,000 years ago. His suggestion has one notable strong point, to my mind. For in Plato's Atlantis story it is stated that the forces of Solon's homeland (Athens) had defeated those of Atlantis before the cataclysm that brought about its disappearance. And of course the most important feature of the Greek legends relating to Troy was the Trojan War itself, and the capture of the city by the Hellenic forces.

Inevitably, however, Zangger has to modify the Platonic data on time and place. Moreover, he accepts both the real existence of the Trojan War (a point disputed by many scholars, most notably the late Sir Moses Finley) and its identification with the site of Schliemann's excavations. These are inevitable difficulties. They are compounded by the special arguments needed to make the Trojan landscape conform to the Platonic description of Atlantis, and by the absence of any satisfactory natural calamity to bring about the disappearance of Troy. For, if correctly identified, the site was still there in classical Greek times, when a temple was built, and remained to await the spade of Schliemann.

Zangger's own recent work has been at the Mycenaean citadel of Tiryns in the
Argolid (southern Greece). There he has found good evidence of a large flood, probably earthquake-induced, that covered much of the lower city with mud around $1200 \mathrm{BC}$. But although much is made of this circumstance in his book, he does not imply a larger, pan-Aegean catastrophe that might have engulfed Troy at that time (and, as noted above, the site of Hissarlik itself remains obstinately un-engulfed, although the topography, and especially the coastline, have certainly changed since then).

This book is well written. The relevant texts from Plato are printed in full and carefully discussed. The case that Zangger is making is not overstated. In one sense it is perhaps understated, because the relevance of his own observations at Tiryns to the history of Troy is not spelt out very clearly, and indeed remains to me obscure. For the sceptic, therefore, for whom even the historical reality of Troy and the identification of Hissarlik with it are problematic, the central thesis that Atlantis was Troy is unpersuasive. As Atlantis books go, this is a perfectly sane and well-argued one, written by a competent scholar. But Aristotle was one of the first to suggest the view, pithily expressed by Francis Cornford in 1937 (and quoted by Zangger), that "serious scholars now agree that Atlantis probably owed its existence entirely to Plato's imagination". Until Egyptologists unearth the hieroglyphic inscriptions upon which Solon's Egyptian informants supposedly relied, I shall incline towards Aristotle and Cornford rather than towards Plato and Zangger.

Colin Renfrew is in the Department of Archaeology, University of Cambridge, Downing Street, Cambridge CB2 3DZ, UK. 